\title{
Composition and Radical Scavenging Activity of Essential Oil from Xylopia aethiopica: A New Chemotype Grown in Nigeria
}

\author{
Ignatius A. Owokotomo, Jamiu M. Jabar, and Omotayo O. Alabi
}

\section{ABSTRACT}

Despite its use in traditional medicines, studies on the radical scavenging activity of the essential oils from Xylopia aethopica from Nigeria have not been widely reported in literature. Thus, in this work, fresh fruits of Xylopia aethopica were air dried, ground and extracted through hydro-distillation using Clevenger-type distillation apparatus. The essential oil was analyzed using Gas Chromatographic/Flame Ionization Detection (GC/FID) Technique and confirmed by gas chromatographic/mass spectrometric (GC/MS) analysis. The radical scavenging activity of the essential oil was evaluated in comparison with butylated hydroxylanisole (BHA) through 1,1Diphenyl-2-picrylhydrazyl (DPPH) scavenging assay. A total of Forty-five compounds were detected through the GC/FID and GC/MS analyses of the essential oil of Xylopia aethopica. The major constituents of the essential oil were $\beta$-pinene $(55.15 \%), \alpha$-thujene $(9.23 \%)$ and $\alpha$-eudesmol $(8.61 \%)$ and $\alpha$ pinene $(6.77 \%)$. Other notable constituents were 1,8 -cineole $(6.13 \%)$, ethyl cinnamate $(5.83 \%)$ and elemol $(5.17 \%)$. The methanolic solution of the essential oil showed concentration-dependent scavenging activity on 1,1Diphenyl-2-Picrylhydrazyl (DPPH) radical. The results of the Scavenging effect of the Xylopia aethopica essential oil compared well with the activity of the commercial radical scavenging agent, Butylated hydroxylanisole (BHA) and this suggests possible uses of the essential oil as sources of natural antioxidants. Data were analyzed using $R$ statistical software.

Keywords: Essential oils, Radical scavenging activity, Xylopia aethiopica, Nigeria.
Published Online: April 30, 2021

ISSN: $2684-4478$

DOI : 10.24018/ejchem.2021.2.2.52

\section{A. Owokotomo*}

Department of Chemistry, School of Sciences, Federal University of Technology, P.M.B 704 Akure, Nigeria. (e-mail: iaowokotomo@futa.edu.ng)

J. M. Jabar

Department of Chemistry, School of Sciences, Federal University of Technology, P.M.B 704 Akure, Nigeria. (e-mail: jmjabar@futa.edu.ng)

O. O. Alabi

Department of Chemistry, School of Sciences, Federal University of Technology, P.M.B 704 Akure, Nigeria. (e-mail: ooalabi@ futa.edu.ng)

*Corresponding Author

\section{INTRODUCTION}

Essential oils (Floral scents) are volatile substances that carry distinctive odours or essence of plants. They can be referred to as active secondary metabolites from plants because they are very potent at trifling amounts which due to large number of compounds that often define their composition [1], [2]. Floral scents are presumed to have evolved during the course of evolution to guarantee subsistence, and this could explain their dual functions in many plants - they attract pollinators but also contain compounds that act to dissuade herbivory [3].

Nigeria is rich with many essential oil bearing plants among which is Xylopia aethopica commonly called Negro pepper and known locally as 'Erunje' in South-West Nigeria. It is a dense forest tree common to West Africa and often found growing in the wild especially along river banks and marshlands [4]. It belongs to the family of Annonaceae, subfamily Annonoidae, tribe is Unoneae, subtribe, Xylopinea [5].

The essential oil from Xylopia aethopica is commonly used against colds and as stimulants and stomachic [2]. Extracts from the plant are used as flavorings in fruit drinks and in traditional medicines in the treatment of arthritis, rheumatism, diarrhea, and dysentery [6]. It is also used in ethno medicine as a lactation stimulant [7], and in the treatment of female sterility and abdominal pains [8]. However, there is the concern that Xylopia aethopica may compromise male fertility [9], [10].

The chemical compositions of essential oils from Xylopia aethopica have been assigned by various authors. In a report, sabinene, 1, 8 - cineole, terpinen - 4 - ol and linalool were the major constituent of the essential oil of Xylopia aethopica from Benin, West Africa [11]. Another report confirmed the presence of $\beta$-pinene, $\gamma$-terpinene, trans-pinocaveol and $\mathrm{p}$ cymene as the major constituent of a sample from Mali [12]. While $\alpha$-pinene, $\beta$-pinene, sabinene, germacrene and 1, 8 cineole was assigned as the major constituent of a Togo variety [13].

Earlier studies of the essential oils from some samples of Xylopia aethopica from Nigeria have been reported as consisting of $\alpha$-pinene and $\beta$-pinene as the major chemical principles [14]. A different researcher identified the presence of 1,8-cineole and terpinen-4-ol as the major constituents of another sample of Xylopia aethopica from Nigeria [15]. Also, recently sabinene, eugenol, acetyl-eugenol, 1,8-cineole were identified as the major constituent of yet another sample from the country [16]. However, literatures on the radical scavenging activity of the essential oils from this plant from Nigeria are not common. 
Disequilibrium between the production of reactive oxygen species $\left(\mathrm{O}_{2} *, \mathrm{OH}^{*}, \mathrm{RO}^{*}, \mathrm{ROO}^{*}\right.$ and $\left.\mathrm{H}_{2} \mathrm{O}_{2}\right)$ and the antioxidant capacity of natural antioxidants (superoxide dismutase, catalase, glutathione, peroxidase, vitamin $\mathrm{C}$, vitamin $\mathrm{E}$ and $\beta$-carotene) in the human body leads to oxidative stress, which contributes to the genesis of a large number of pathological frames, resultant from structural damages caused by the oxidation of protein and lipid peroxidation [17].

Endogenous antioxidants like superoxide dismutase, catalase, glutathione peroxidase, uric acid, bilirubin, albumin, provide the natural defense against free radicals. However, exogenous antioxidants like vitamin $\mathrm{E}$, vitamin $\mathrm{C}, \beta$-carotene, vitamin E, flavonoids and synthetic compounds, like butylhydroxyanisole (BHA), butylhydroxytoluene (BHT), gallates, etc., may be required when a complete protection of the organism cannot be achieved by the endogenous factors [18], [30]. However, due to environmental concern and fret over the toxic side effects of synthetic antioxidants like butylated hydroxylanisole (BHA) and butylated hydroxyltoluene (BHT), several studies have in recent years, focused on the uses of essential oils as potential sources of safe antioxidants [19].

The free radical method using 1,1-diphenyl-2-picrylhydrazyl (DPPH) is a well-established assay for the in-vitro determination of antioxidant activity in food and biological extracts [31]. DPPH • (1,1-diphenyl-2-picryl-hydrazyl) is a stable free radical, due to the delocalization of the spare electron on the whole radical molecule. When DPPH• reacts with a hydrogen donor, the reduced (molecular) form (DPPH) is generated, accompanied by the disappearance of the violet colour, with an absorption band with a maximum around 520 $\mathrm{nm}[30]$.

Thus in this study, we investigate the chemical constituents and the radical scavenging activity of the essential oil from the fruits of $X$. aethopica grown in South West Nigeria.

\section{MAterials AND METHODS}

\section{A. Sample Collection \& Preparation}

The fruits of $X$. aethiopica were purchased from a farmer at Ado-Ekiti, Ekiti State, Nigeria (Fig. 1) and were air dried in the laboratory for three weeks. Fig. 1 shows the picture of the dried sample of $X$. aethiopica used in this experiment.

\section{B. Essential Oil Extraction}

The dried fruits of $X$. aethiopica were pulverized using a wooden mortar and pestle. The pulverized fruits were transferred into a two liter round bottom flask which was connected to an all-glass Clevenger-type distillation apparatus. The sample was distilled continuously for three hours until there was no appreciable increase in the volume of essential oil. The essential oil was collected into an airtight sample bottle and stored in the refrigerator without any further treatment prior to analysis.

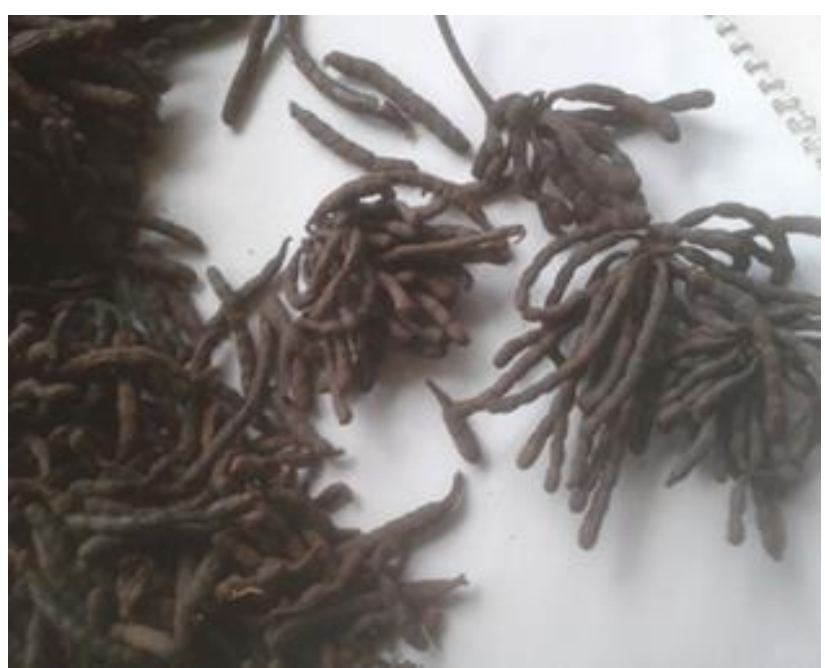

Fig. 1. Dried sample of Xylopia aethiopica fruits.

\section{Chemical analysis of the Essential Oil}

Chemical analysis of the extracted essential oil was achieved through a Perkin-Elmer Auto System (HP 6890/ HP ChemStation Rev. A09.01 (1206) Software) GC, integrated with a dual Flame Ionization Detection (FID) system. The oven temperature was programmed from $40{ }^{\circ} \mathrm{C}$ to $200{ }^{\circ} \mathrm{C}$ for 2 minutes. The detector temperature was maintained at 300 ${ }^{\circ} \mathrm{C}$. The injection type was a split mode system and hydrogen was the carrier gas set at a flow rate of $1.0 \mathrm{~mL} / \mathrm{minute}$.

The GC/MS analysis was achieved through a Shimadzu GC-MS (QP5050A) series. The column capillary was DB-5; $30.0 \mathrm{~m}$ (length) $\times 0.25 \mathrm{~mm}$ (diameter) $\times 0.25 \mu \mathrm{m}$ (film thickness). Helium was the carrier gas running at constant flow rate of $2.0 \mathrm{~mL} / \mathrm{min}$. Temperature was set $80^{\circ} \mathrm{C}$ and held for 2.0 minutes and increased by $10{ }^{\circ} \mathrm{C} / \mathrm{min}$ to a final temperature of $240{ }^{\circ} \mathrm{C}$ for 6.0 minutes. Sample injection volume was $1.0 \mu \mathrm{L}$. The spectrometric data were integrated through AMDIS (Automated Mass Spectral de-convolution and identification System) software. The retention indices (RI) were in relation to a homologous series of n-alkanes $\left(\mathrm{C}_{7}-\right.$ $\mathrm{C}_{30}$ ) on the DB-5 column under the same chromatographic conditions. Essential oil compositions were identified by comparison of the mass spectral fragmentation data with the NIST standard data bank (NIST Mass Spectral Search Program for the NIST/EPA/NIH Mass Spectral Library, version 2002 to 2006) and data from literature [32].

\section{DPPH Radical Scavenging Activity Analysis of the Essential Oil}

The DPPH radical scavenging activity analysis of the essential oil of $X$. aethiopica was carried out using a procedure described in literature [33], with some modification [20]. The procedure involved preparing different concentrations of the essential oil in the range of 5.0 $\mathrm{mg} / \mathrm{mL}, 10.0 \mathrm{mg} / \mathrm{mL}$ up to $30.0 \mathrm{mg} / \mathrm{mL}$ using methanol. A stock solution $(50.0 \mu \mathrm{L})$ of each sample was then placed in a cuvette and $2.0 \mathrm{~mL}$ of $60.0 \mu \mathrm{M}$ solution of 1,1-Diphenyl-2picrylhydrazyl (DPPH) solution in methanol was added and absorbance measured at $517 \mathrm{~nm}$ using a uv-visible spectrophotometer after 60 minutes of incubation. The same procedure was followed to determine the scavenging effect of butylated hydroxylanisole (BHA) on the DPPH radical to compare with that of the essential oil. A blank sample 
containing only methanol and DPPH solution was also tested as a control. All readings were taken in triplicate and the percentage scavenging effect on the DPPH radical was then calculated as follows:

\% DPPH Scavenging effect $=$ $=\frac{\text { Absorbance of Control }- \text { Absorbance of Sample }}{\text { Absorbance of Control }} \times 100$

\section{E. Statistical Analysis}

We performed Analysis of variance (ANOVA - [14]) to check if there is a significant difference in the average effect of the two treatments (BHA and Essential oil of $X$. aethiopica) on 1,1-diphenyl-2-picryl-hydrazyl radical $(\mathrm{DPPH} \cdot)$. Although we have only two treatment groups, we decided on ANOVA because of the presence of a dose effect with more than two groups. Moreover, the ANOVA technique allows estimating the possible interaction between the treatment groups and Dose. In other words, we can examine if the average effect of the two treatments differs by dose groups with ANOVA. Furthermore, we performed a post-hoc analysis using the results from the ANOVA to establish the superiority of a treatment [14]. Finally, we tested to ensure that all assumptions of ANOVA were satisfied (see appendix A for the ANOVA model formulation and assumptions). All analysis was performed using R statistical software at $5 \%$ level of significance.

\section{RESUlTS AND DisCUSSIONS}

\section{A. Chemical composition of the Essential oil}

The Gas Chromatography-Flame Ionization Detection (GC/FID) and GC/MS analyses revealed the presence of forty-five chemical compounds (Table I). Only seven (Fig. 2) were present in appreciable quantities with the remaining thirty-eight occurring below $0.01 \%$. The major constituents of the essential oil identified were $\beta$-pinene $(55.15 \%) \underline{\mathbf{1}}, \alpha$ thujene $(9.23 \%) \underline{\mathbf{2}}$, and $\alpha$-eudesmol $(8.61 \%) \underline{\mathbf{3}}$, and $\alpha$-pinene $(6.77 \%) \underline{4}$. Others were 1,8 -cineole $(6.13 \%) \underline{\mathbf{5}}, \beta$-bisabolene $(5.83 \%) \underline{6}$ and elemol $(5.17 \%) \underline{7}$. The following are the chemical structures of the major compounds present in the essential oil of $X$. aethiopica.

The presence of $\alpha$-pinene, $\beta$-pinene and 1,8-cineole as the major constituents of the essential oil from the present sample of $X$. aethiopica denotes a similarity with the previous reports from Nigeria [14]-[16]. However, the presence of thujene, elemol, $\beta$-bisabolene and eudesmol in significant amounts presents a major alteration. Thus, it may be inferred that the current sample of $X$. aethiopica is a different and new chemotype that is now reported for the first time.

TABLE I: CHEMICAL CONSTITUENTS OF THE ESSENTIAL OIL OF THE FRUITS OF XYLOPIA AETHIOPICA

\begin{tabular}{|c|c|c|c|c|}
\hline $\mathrm{S} / \mathrm{N}$ & $\begin{array}{l}\text { Chemical } \\
\text { compounds }\end{array}$ & $\begin{array}{l}\text { Retention } \\
\text { time }\end{array}$ & $\begin{array}{c}\text { Retention } \\
\text { index } \\
\text { Percentage }\end{array}$ & $\begin{array}{c}(\mathrm{Rt})(\mathrm{RI}) \\
\text { composition } \\
(\%)\end{array}$ \\
\hline 1 & O-cymene & 6.35 & 1041.0 & 0.0013 \\
\hline 2 & sabinene & 7.29 & 973.0 & 0.0013 \\
\hline 3 & $\alpha$-Pinene & 9.69 & 936.1 & 6.77 \\
\hline 4 & $\beta$-Pinene & 11.37 & 977.7 & 55.15 \\
\hline 5 & 2-carene & 12.09 & 1001 & 0.00071 \\
\hline 6 & myrecene & 12.31 & 994 & 0.0011 \\
\hline 7 & E-ocimene & 12.52 & 1050 & 0.0032 \\
\hline 8 & $\delta$-limonene & 12.83 & 1039 & 0.0012 \\
\hline 9 & allo-ocimene & 13.51 & 1117.8 & 0.0016 \\
\hline 10 & (1S)-1(-1)-pinene & 13.82 & 981 & 0.0013 \\
\hline 11 & Z-ocimene & 14.06 & 1040 & 0.00024 \\
\hline 12 & $\alpha$-thujene & 14.50 & 931 & 9.30 \\
\hline 13 & elemol & 15.02 & 1547.5 & 5.17 \\
\hline 14 & geranial & 15.39 & 1270.3 & 0.0016 \\
\hline 15 & $\gamma$-terpenene & 15.98 & 1059.7 & 0.0034 \\
\hline 16 & iso-artemisia & 16.67 & 1083.1 & 0.0013 \\
\hline 17 & geraniol & 17.19 & 1270.3 & 0.0013 \\
\hline 18 & nerol & 17.50 & 1228.9 & 0.0018 \\
\hline 19 & eugenol & 17.53 & 1335 & 0.0013 \\
\hline 20 & 1,8-cineole & 17.70 & 991 & 6.13 \\
\hline 21 & linalool & 18.01 & 1098 & 0.00056 \\
\hline 22 & $\alpha$-terpineol & 18.68 & 939 & 0.0018 \\
\hline 23 & terpenen-4-ol & 18.77 & 1177 & 0.0015 \\
\hline 24 & thymol methylether & 19.73 & 1235 & 0.0017 \\
\hline 25 & $\alpha$-farnesene & 20.42 & 1508 & 0.0017 \\
\hline 26 & thymyl ethylether & 20.79 & 763 & 0.0024 \\
\hline 27 & $\beta$-farnesene & 21.40 & 1458 & 0.0031 \\
\hline 28 & linalyl acetate & 21.52 & 1327 & 0.0039 \\
\hline 29 & ethyl cinnamate & 21.99 & 1460 & 5.83 \\
\hline 30 & $\beta$-sesquiphellandrene & 22.22 & 1149 & 0.0034 \\
\hline 31 & $\beta$-bisabolene & 22.57 & 1509 & 0.002 \\
\hline 32 & $(\mathrm{E}, \mathrm{E})$-fernesol & 22.75 & 1721 & 0.0028 \\
\hline 33 & $\beta$-caryophyllene & 22.90 & 1418 & 0.0026 \\
\hline 34 & spathulenol & 23.35 & 1575 & 0.00076 \\
\hline 35 & t- $\alpha$-bergamotene & 24.02 & 1434 & 0.0030 \\
\hline 36 & $\beta$-elemene & 24.44 & 1375 & 0.0030 \\
\hline 37 & bicyclogermacrene & 25.26 & 1494 & 0.0025 \\
\hline 38 & $\alpha$-copane & 25.75 & 1376 & 0.0011 \\
\hline 39 & acetyleugenol & 26.95 & 1520 & 0.0011 \\
\hline 40 & elemicin & 27.07 & 1554 & 0.053 \\
\hline 41 & $\alpha$-humulene & 27.48 & 1455 & 0.00090 \\
\hline 42 & gamma muurolene & 28.02 & 1477 & 0.0021 \\
\hline 43 & $\alpha$-selinene & 28.76 & 1494 & 0.0055 \\
\hline 44 & $\alpha$-eudesmol & 29.22 & 1652 & 8.61 \\
\hline \multirow[t]{2}{*}{45} & velerinol & 29.91 & - & 2.91 \\
\hline & Total & & & $100.0 \%$ \\
\hline
\end{tabular}

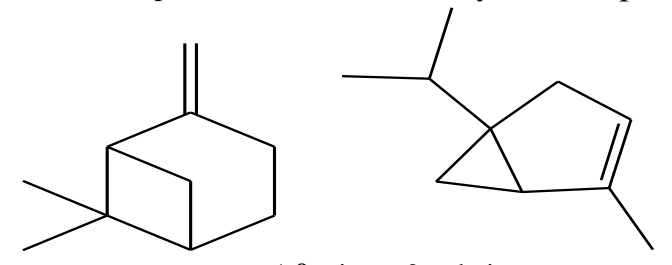

$1 \beta$-pinene $2 \alpha$-thujene

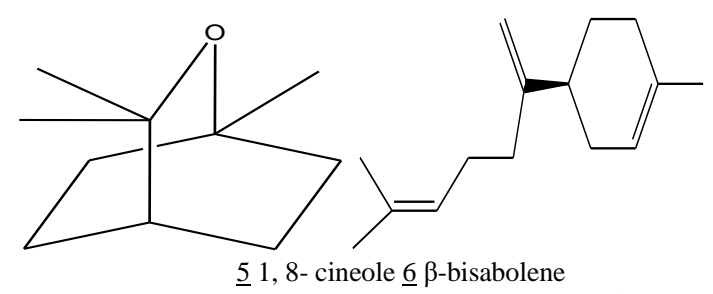<smiles>CC1=C(C)C2C[C@H](C(C)(C)O)CC[C@]2(C)CC1</smiles><smiles>CC1=CCC2CC1C2(C)C</smiles>

Fig. 2. The major constituents of X. aethiopica. 


\section{B. DPPH Radical Scavenging Activity of the Essential Oil}

To obtain an overview of the average effect of the two treatments, and dose on DPPH radical, we obtained the average DPPH radical for the two treatments and also for each dose. We present these in Fig. 3. The average of DPPH radical for BHA is higher than that of the essential oil, while the variability of the two treatments is quite similar (panel A in Fig. 3). Although, this is without taking the dose effect into account, this already points at a potential difference in the effect of both treatments on DPPH radical. Regarding the dose effect on DPPH radical, the average DPPH radical scavenged increased with increasing dose. However, the average DPPH radical scavenged as well as the variability around those means for the last three dose levels (20, 25, 30 $\mathrm{mg} / \mathrm{ml}$ ) are essentially equal (panel B in Fig. 3). The variability in DPPH radical is highest at $10 \mathrm{mg} / \mathrm{ml}$ and lowest at $5 \mathrm{mg} / \mathrm{ml}$. Panel $\mathrm{C}$ in Fig. 3 shows the interaction plot. Generally, BHA has a higher average DPPH radical scavenged compared to the essential oil irrespective of the dose. This implies there might be no interacting effect of the dose and treatment on the scavenging effect.

The test of the interaction effect was done in order to confirm if indeed there is no interaction between the dose and the effect of the treatments on the DPPH radical. To achieve this, we compared two ANOVA models, one with the interaction effect (model 2) and another without the interaction effect (model 1). The p-value of the test is 0.1642 , which is greater than our specified level of significance. Thus, we do not have sufficient evidence to reject the null hypothesis so we can conclude that there is no interaction effect of the treatment and dose on DPPH radical (Table IV in appendix). We proceed to use model 1 for the rest of the analysis. The treatment and the dose have a significant effect on the effect on DPPH since the test for the difference in means for both variables have p-values lesser than the specified level of significance (Table II). This implies that the mean DPPH scavenged by the BHA is significantly different from the essential oil. Also, the mean DPPH scavenged is different per dose.

TABLE II: REDUCED ANOVA. TREATMENT AND DOSE EFFECT

\begin{tabular}{cccc}
\hline & Mean SQ & F-value & P-value \\
\hline Treatment & 1.62255 & 247.51 & 0.00 \\
Dose & 0.73948 & 112.80 & 0.00 \\
Residuals & 0.00656 & & \\
\hline
\end{tabular}

Mean Sq = Mean squares. The null hypothesis is no significant difference in the means for the treatments and dose.

All ANOVA assumptions such as normality of the error term and constancy of variance were satisfied for (See appendix C).

\begin{tabular}{ccccc}
\multicolumn{5}{c}{ TABLE III: COMPARISON OF TREATMENT MEANS } \\
\hline & $\begin{array}{c}\text { Estimated } \\
\text { means }\end{array}$ & $\begin{array}{c}\text { STD. } \\
\text { error }\end{array}$ & T-value & P-value \\
\hline BHA & 3.99 & & & \\
Essential oil & 3.57 & & & \\
Difference & 0.42 & 0.03 & 15.73 & 0.00 \\
\hline
\end{tabular}

The null hypothesis is testing that the mean DPPH scavenged for BHA is similar to that of essential oil against an alternative that the mean of DPPH scavenged for BHA is significantly higher than that of essential oil.
The post hoc analysis presented in Table III shows that essential oil has a significant lower effect as compared to the BHA on the DPPH radical since the p-value for the null hypothesis indicates that there is sufficient evidence that the mean of BHA is significantly higher than that of essential oil.

However, the scavenging effect of $X$. aethiopica essential oil fared comparably with the commercial radical scavenging agent, Butylated hydroxylanisole (BHA). The synergistic functions of the various components of essential oils may be the reason for their potency [21]-[23]. Thus, the presence of a vast number of compounds with diverse functionality in this essential oil may be the reason for its potent effect on the DPPH radical.
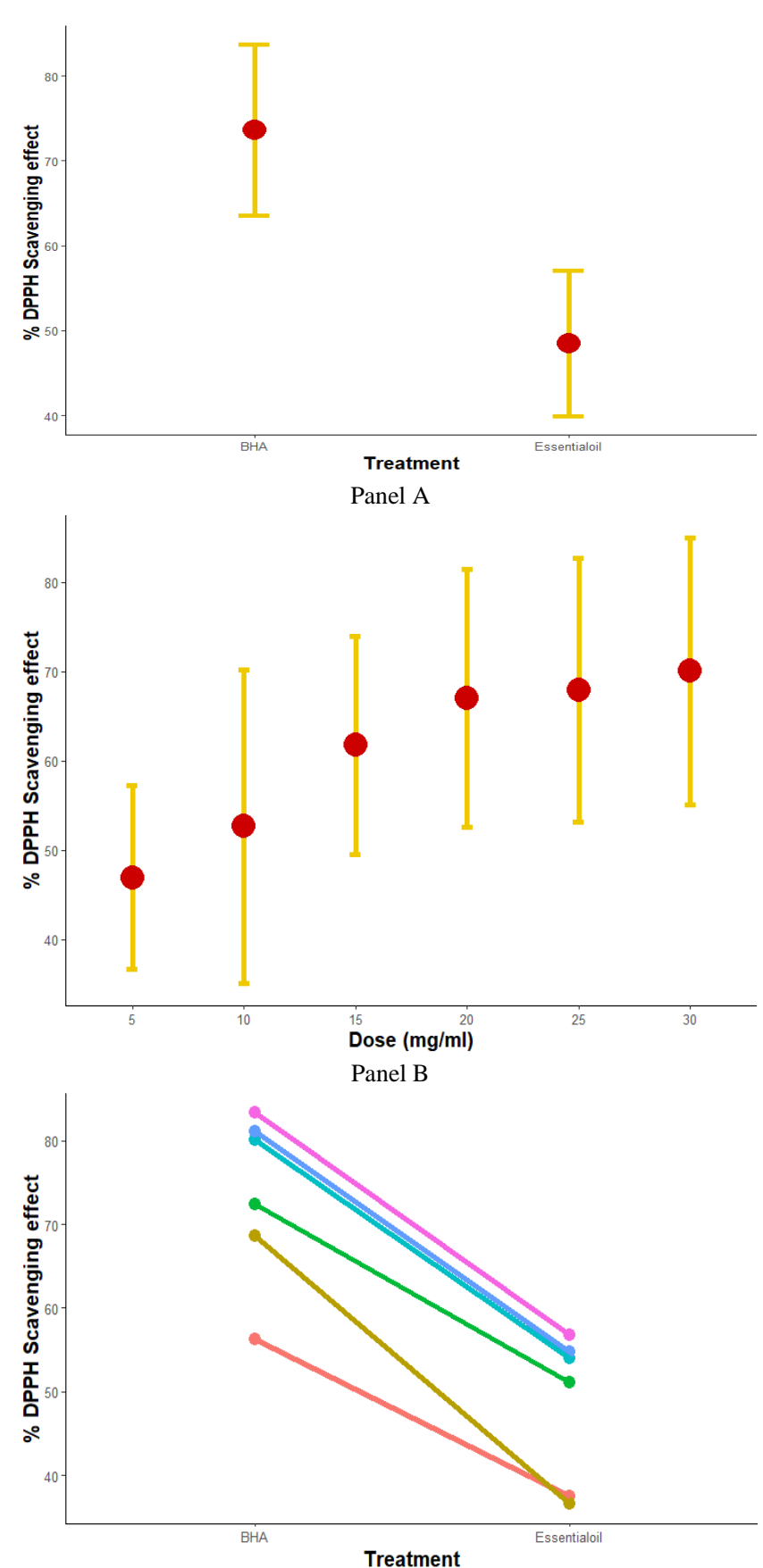

$$
\text { Dose }(\mathrm{mg} / \mathrm{ml}) \div 5 \div 15 \div 25
$$

Panel C

Fig. 3. Average Radical per treatment (A), per dose (B), and per treatment-dose combination. (Each point is the computed mean, while the vertical lines in A and B are the variability around the computed means). 


\section{CONCLUSIONS}

The results obtained from this research indicate that the essential oil composition of the current sample of Xylopia aethiopica differs from previous reports in literature and may be classified as a new chemotype. The fruits of Xylopia aethiopica possess natural radical scavenging agents. The anti-radical potency of the essential oil was comparable to that of the synthetic antioxidant, BHA. The antioxidant activity of the essential oil may be as a result of the synergistic effect of large number of compounds (45 compounds) present in the essential oil. More so, essential oils are composed of terpenes and phenolic compounds which are known to have antioxidant properties [24], [25]. This research showed that Xylopia aethiopica fruit essential oil is a potential source of phytochemicals with useful pharmaceutical applications.

\section{APPENDIX}

\section{A. ANOVA Model Formulation}

The $\%$ Scavenging effect on DPPH radical was assumed to follow a normal distribution as this is a continuous outcome. Let $Y_{-}$ijk be the \% DPPH Scavenging effect for the kth observation $(\mathrm{k}=1,2,3)$ for the $i^{\text {th }}$ treatment $(i=1,2)$ at the $j^{\text {th }}$ dose level $(j=1,2,3,4,5,6)$, then using the cell means formulation of the analysis of variance

$$
\begin{gathered}
Y \_i j k=\backslash m u \_i j+\text { lepsilon_ijk....................model } 1 \\
\backslash m u \_i j=\backslash m u . . .+ \text { \alpha_i }+ \text { Ibeta_j }+(\text { (lalphalbeta }) i j
\end{gathered}
$$

where \alpha_i is the the effect of the $i^{\text {th }}$ treatment effect, lepsilon_ijk are independent $\mathrm{N}(0$, Isigma2)

$\mathrm{i}=1, \ldots, \mathrm{a} ; \mathrm{j}=1, \ldots, \mathrm{b} ; \mathrm{k}=1, \ldots, \mathrm{n}$

The model formulation in (1) assume that:

1) The parameter $\backslash \mathrm{mu}$ _ij is the mean $\%$ Scavenging effect on DPPH radical at tratement $j$ and dose level $i$, this is because $\mathrm{E}($ lepsilon_ijk $)=0$ and therefore $\mathrm{E}\left(\mathrm{Y} \_\mathrm{ijk}\right)=0$.

2) Since $\backslash m u \_i j$ is a constant, the variance of $Y \_i j k$ is:

$$
\backslash \operatorname{sigma} 2\left(Y \_i j k\right)=\backslash \operatorname{sigma} 2(\backslash \text { epsilon_ijk })=\backslash \operatorname{sigma} 2 .
$$

3) Since the error term are normally and independently distributed, so are the observations Y_ijk. Hence, the ANOVA model in equation (1) can also be stated as follows:

$$
\text { Y_ijk are independent } \mathrm{N}\left(\backslash \mathrm{mu} \_\mathrm{ij}\right. \text {, \sigma2). }
$$

\section{B. Extra Tables}

\section{Test of interaction effect}

$\mathrm{H}_{0}$ : There is no difference between models 1 and 2 . Hence, there is no significant interacting effect of the treatment and dose on DPPH.

TABLE IV: MODEL COMPARISON BETWEEN THE MODEL WITHOUT INTERACTION (MODEL 1) AND THAT WITH THE INTERACTION EFFECT (MODEL 2)

\begin{tabular}{ccccc}
\hline Model & DF & RSS & F & $\operatorname{Pr}(>\mathrm{F})$ \\
\hline 1 & 32 & 0.20344 & 2.027 & 0.1642 \\
2 & 33 & 0.21633 & & \\
\hline
\end{tabular}

\section{Test for ANOVA Model Assumptions}

$\mathrm{H}_{0}$ : The variance of the residuals from the model is constant.

TABLE V: TEST FOR CONSTANCY OF VARIANCE FOR MODEL 1

\begin{tabular}{|c|c|c|}
\hline \multicolumn{3}{|c|}{ Test for Normality Assumption } \\
\hline Test & Statistic & $\mathrm{P}$-value \\
\hline Shapiro-Wilk & 0.95 & 0.15 \\
\hline Kolmogorov-Smirnov & 0.12 & 0.67 \\
\hline Anderson-Darling & 0.47 & 0.24 \\
\hline
\end{tabular}

$\begin{array}{cc}\text { Breusch Pagan Test for Constancy of Variance } \\ \text { DF } & 1 \\ \mathrm{X}^{2} & 1.74 \\ \text { P-VALUE } & 0.19\end{array}$

$\mathrm{H}_{0}$ : The error term from model is normally distributed.

TABLE VI: TEST FOR NORMALITY OF THE RESIDUALS FOR MODEL 1

\section{REFERENCES}

[1] Asekun OT and Adeniyi BA. Antimicrobial and cytotoxic activities of the fruit essential oil of Xylopia aethiopica from Nigeria. Fitoterapia. 2004; 75(3-4): 368-370.

[2] Ekundayo O. Essential oil composition of some Nigerian Medicinal Plants. Progress in Essential oil research. E. J. Brunke (Ed.). Walter de Gruyter \& Co., Berlin. New York. 1986; Pp: 69-84.

[3] Meekijjaroenroj A, Bessière J and Anstett M. Chemistry of floral scents in four Licuala species (Arecaceae). Flavour Fragr. J. 2007; 22: 300310 .

[4] Thomas A. Les annonacees. Museum national d'Histoire Naturelle, Paris. 1996; pp :371.

[5] Ayedoun AM, Adeoti BS and Sossou PV. Influence of fruit conservation methods on the essential oil composition of Xylopia aethiopica (Dunal) A. Richard from Benin. Flav. Fragr. J. 1996; 11: 245.

[6] Karioti A, Hadjipavlou-Litina, D, Mensah MLK, Fleischer TC and Skaltsa H. Composition and antioxidant activity of the essential oils of Xylopia aethiopica (Dun) A. Rich. (Annonaceae) leaves stem bark root bark and fresh and dried fruits growing in Ghana. J. Agr. Food Chem. 2004; 52(26): 8094-8098.

[7] Tchiegang $\mathrm{C}$ and Mbougueng PD. Composition chimique des épices utilisées dans la préparation du Nah-poh et du Nkui de l'Ouest Cameroun. Tropicultura, 2005; 23: 193-200.

[8] Anvam ZPH. Extraction et and analyse des huiles essentielles de trios especes de la famille des annonacees du Cameroun. Faculte des Sciences, Yaounde. 1998; pp. 27

[9] Adienbo,OM, Nwafor A, Dapper DV. Impairments in testicular function indices in male Wister rats: a possible mechanism for infertility induction my Xylopia aethopica Fruit extract. Int J Reprod Contracept Obstet Gyneco. 2015; 4(1): 71-75.

[10] Nwangwa KE. Antifertility effects of Ethanoic Extract of Xylopia aethiopica on male reproductive organs of Wister Rats. American Journal of Medicine and Medical Sciences. 2012; 2 (10): 12-15.

[11] Poitou F, Masotti V, de Soaza SG, Viano J and Gaydou EM. Composition of the essential oil of Xylopia aethiopica dried fruits from Benin. Journal of Essential oil research. 1996; 8(3): 329-330.

[12] Kaita B, Sidibe L, Figuered G and Chalchat H. Chemical composition of the essential oil of Xylopia aethiopica (Dunal) ACh from Mali. Journal of Essential oil research. 2003; 15(4): 267-269.

[13] Koba K, Sanda K, Raynaud C, Guyun C, Chaumont J and Nicod L. Chemical composition and in-vitro cytotoxic activity of Xylopia aethiopica (Dunal) A.Rich (Annonaceae) fruits from Togo. Journal of Essential oil research. 2011; 5(4): 354-357.

[14] KUTNER, MH, Nachtsheim, C., Neter, J., \& Li, W. (2005). Applied linear statistical models.

[15] R Core Team (2020). R: A language and environment for statistical computing. R Foundation for Statistical Computing, Vienna, Austria. URL http://www.R-project.org/.

[16] Fox J, Weisberg S (2019). An \{R $\}$ Companion to Applied Regression, Third Edition. Thousand Oaks CA: Sage.URL: https://socialsciences.mcmaster.ca/jfox/Books/Companion/.

[17] Hothorn T, Bretz F and Westfall P (2008). Simultaneous Inference in General Parametric Models. Biometrical Journal 50(3), 346--363.

[18] Ekundayo O. A review of the volatiles of Annonaceae. Journal of Essential Oil Research. 1989; 1: 223. 
[19] Uguoru CU, Pilla C and Olasan JO. hytochemical screening of Xylopia aethiopica with emphasis on its medicinally active principles. J. Med. Plants Res. 2016; 10 (22): 306-309.

[20] Usman, LA, Akolade JO, Odebisi BO and Olanipekun B. Chemical composition and antimicrobial activity of fruit essential oil of Xylopia aethiopica D. grown in Nigeria. Journal of Essential oil bearing plants. 2016; 19: 648-655.

[21] de-Miranda ALP and Fraga CAM. Free radical scavenger activity: Determination of the antioxidant profile of bioactive substances. www.iupac.org/publications/cd/medicinal_chemistry/ 1 December, 2006.

[22] Sílvia M, Albano A, Lima S, Miguel G, Pedro G L, Barroso JG and Figueiredo, AC. Antioxidant, Anti-5-lipoxygenase and Antiacetylcholinesterase activities of essential oils and decoction waters of some aromatic plants. Records of natural products. 2012; 6(1): 35-48.

[23] Raza AS, Rehman-ur-Aziz, Adnan A and Qureshi F. Comparison of antioxidant activity of essential oil of Centella asiatica and Butylated hydroxyanisole in sunflower oil at ambient condition. Biharean Biologist. 2009; 3(1): 71-75.

[24] Sílvia M, Albano A, Lima S, Miguel G, Pedro G L, Barroso JG and Figueiredo A C. Antioxidant, Anti-5-lipoxygenase and Antiacetylcholinesterase activities of essential oils and decoction waters of some aromatic plants. Records of natural products. 2012; 6(1): $35-48$.

[25] Franzios G, Mirotsou M, Kral J, Scouras ZG, Mavragani-Tsipidou P. Insecticidal and genotoxic activities of mint essential oils. Journal of Agriculture and Food Chemistry. 1997; 45: 2690-2694.

[26] Hoet S, Ste'vigny C, He'rent MF, Quetin-Leclercq J. Antitrypanosomal compound from leaf essential oil of Strychnos spinosa. Planta Medica. 2006. 72: 480-482.

[27] Bakkali F, Averbeck S, Averbeck D, Idaomar M. Biological effects of Essential oils - A review. Food and Chemical Toxicology. 2008; 46: 446-475.

[28] Oyedeji OA and Adayan AJ. Chemical composition and antibacterial activity of essential oil of Centella asiatica growing in South Africa. Pharmaceutical Biology. 2005; 43(3): 381-384.

[29] Jirovetz L, Buchbauer G and Ngassoum M. Investigation of the essential oils from the dried fruits of Xylopia aethiopica (West African "peppertree" and Xylopia parviflora from Cameroon. Ernahrung. 1997; 21: 1 .

[30] Pisoschi, A.M and Negulescu, G. P (2011). Methods for Total Antioxidant Activity Determination: A Review. Biochem \& Anal Biochem, 1:1z. DOI: 10.4172/2161-1009.1000106.

[31] Bedlovi`cová. Z, Strapá c. I, Baláž. M and Salayová. A. (2020) A Brief Overview on Antioxidant Activity Determination of Silver Nanoparticles. Molecules 25, 3191; doi:10.3390/molecules25143191.

[32] Adams, R. P. 1995. Identification of essential oil components by gas chromatography/mass spectroscopy. Allured Publishing Corporation, Illinois, USA. 5-115.

[33] Brand-Williams, W; Cuvelier, M. E and Berset, C. 1995. Use of a free radical method to evaluate antioxidant activity. Sílvia, M; Albano, A; Lima, S; Miguel, G; Pedro, G. L; Barroso, J. G and Figueiredo, A. C. 2012. Antioxidant, Anti-5-lipoxygenase and Antiacetylcholinesterase activities of essential oils and decoction waters of some aromatic plants. Records of natural products 6.1: 35-48. 